Cybernetics: Journal Educational Research and Social Studies

Volume 2, Nomor 3, Juli 2021

Journal Homepage: http://pusdikra-publishing.com/index.php/jrss

\title{
Profesionalisme Guru Pasca Sertifikasi Di MTS Darussaadah Kec. Pangkalan Susu Kab. Langkat
}

\author{
Ahmad Zaki ${ }^{1}$, Nuraini ${ }^{2}$ \\ ${ }^{1}$ UIN Sumatera Utara Medan, Indonesia \\ 2STAI Jam'iyah Mahmudiyah
}

\begin{tabular}{cl}
\hline & \multicolumn{1}{c}{ ABSTRACT } \\
\cline { 2 - 3 } & Penelitian ini bertujuan untuk mengetahui profesionalisme guru pasca \\
& sertifikasi di mts darussaadah kec. pangkalan susu kab. Langkat. Tujuan \\
& pendidikan Nasional yang tercantum dalam UUD 1945 adalah untuk \\
& memajukan kesejahteraan umum, mencerdaskan kehidupan bangsa dan \\
ikut melaksanakan ketertiban dunia berdasarkan kemerdekaan, \\
Anformasi & perdamaian abadi dan keadilan sosial. Dari salah satu tujuan pendidikan \\
nasional yang tercantum dalam UUD 1945 yaitu mencerdaskan \\
Dikirim & kehidupan bangsa, maka faktor pendidikan merupakan faktor yang \\
Revisi & sangat menentukan. hasil penelitian diatas penulis dapat mengambil \\
04 Juli 2021 & kesimpulan sebagai berikut : 1) Kinerja guru pendidikan agama islam \\
Diterima & MTs Darussaadah Kab. Langkat dilihat dari hasil asian instrumen \\
06 Juli 2021 & Denilaian kinerja guru rata-rata mempunyai hasil nilai yang baik, 2) \\
& terdapat faktor-faktor pendukung antara lain: a) Adanya kemauan untuk \\
& maju sehingga mendorong para guru berbuat lebih baik, b) Kerjasama \\
& yang baik antara kepala madrasah/sekolah, guru dan para staf-staf \\
& pembantu. Dan Adanya supervisi yang dilakukan baik oleh kepala \\
& maupun pengawas.
\end{tabular}

Kata Kunci

Profesionalisme Guru, Pasca Sertifikasi

\section{PENDAHULUAN}

Tujuan pendidikan Nasional yang tercantum dalam UUD 1945 adalah untuk memajukan kesejahteraan umum, mencerdaskan kehidupan bangsa dan ikut melaksanakan ketertiban dunia berdasarkan kemerdekaan, perdamaian abadi dan keadilan sosial. Dari salah satu tujuan pendidikan nasional yang tercantum dalam UUD 1945 yaitu mencerdaskan kehidupan bangsa, maka faktor pendidikan merupakan faktor yang sangat menentukan.

Firman Allah juga menegaskan bahwa,Allah SWT memberi keutamaan serta kemulyaan bagi orang-orang yang berilmu.

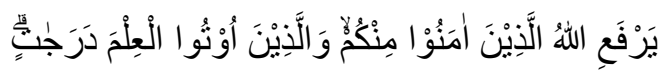


"Allah akan meninggikan orang-orang yang beriman di antaramu dan orangorang yang diberi ilmu pengetahuan beberapa derajat"

Pada UUD 1945 disebutkan, setiap warga negara berhak mendapatkan pendidikan dan pasal (5) disebutkan negara memprioritaskan anggaran pendidikan sekurang-kurangnya $20 \%$ dari anggaran pendapatan belanja negara serta dari anggaran pendapatan dan belanja daerah untuk memenuhi kebutuhan penyelenggaraan pendidikan nasional. Selanjutnya diatur lebih lanjut dalam Undang-Undang Nomor 20 tahun 2003 tentang Sistem Pendidikan Nasional dan UU RI Nomor 14 tahun 2005 tentang guru dan dosen.

Sholeh (2006:13) Dalam mencapai tujuan pendidikan, guru adalah sebagai ujung tombak, sehingga untuk mencapai tujuan tersebut seorang guru harus menjadi guru yang profesional. Sebagaimana yang tercantum dalam UU RI Nomor 14 tahun 2005 tentang guru dan dosen, Bab 1 pasal 1 disebutkan bahwa guru adalah pendidik profesional dengan tugas utama mendidik, mengajar, membimbing, mengarahkan, melatih, menilai dan mengevaluasi peserta didik pada pendidikan anak usia dini jalur pendidikan formal pendidikan menengah.

Kualitas pendidikan tidak akan terwujud walaupun didukung oleh kurikulum yang sempurna, buku-buku pelajaran yang lengkap dan sarana prasarana yang tersedia, apabila guru-guru yang melaksanakan pembelajaran kurang berkualitas, oleh karena itu di tangan guru yang berkualitas diharapkan akan membentuk sumber daya manusia yang berkualitas pula.

Dengan demikian, profesi mengajar adalah sebuah kewajiban yang merupakan manifestasi dari ibadah. Sebagai konsekwensinya, barang siapa yang menyembunyikan sebuah pengetahuan maka ia telah melangkahkan kaki menuju jurang api neraka. Menyadari akan pentingnya profesionalisme dalam pendidikan, maka Ahmad Tafsir mendefinisikan bahwa profesionalisme adalah paham yang mengajarkan bahwa setiap pekerjaan harus dilakukan secara profesional. Dalam Islam setiap pekerjaan harus dilakukan oleh orang yang profesional, dalam arti harus dilakukan secara benar dan itu hanya dilakukan oleh orang yang ahli. Rasulullah SAW bersabda:

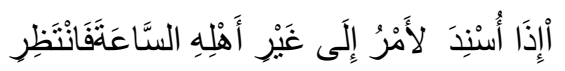

(“Bila suatu urusan dikerjakan oleh orang yang tidak ahli, maka tunggulah kehancurannya")

Akan tetapi melihat realita yang ada, keberadaan guru profesional sangat jauh dari apa yang dicita-citakan. Menjamurnya sekolah-sekolah yang rendah mutunya memberi suatu isyarat bahwa guru profesional hanyalah sebuah wacana yang belum terealisasi secara merata dalam seluruh pendidikan yang ada di Indonesia. Hal itu menimbulkan suatu keprihatinan yang tidak 
hanya datang dari kalangan akademisi, akan tetapi orang awam juga ikut mengomentari ketidakberesan pendidikan dan tenaga pengajar yang ada. Kenyataan tersebut menggugah kalangan akademisi, sehingga mereka membuat perumusan untuk meningkatkan kualifikasi guru melalui pemberdayaan dan peningkatan profesionalisme guru dari pelatihan sampai dengan intruksi agar guru memiliki kualifikasi pendidikan minimal Strata 1 (S1).Menurut Yamin (2009:52) "Standart Kompetensi dan sertifikasi guru merupakan salah satu terobosan dunia pendidikan dalam meningkatkan kualitas guru, sehingga kedepan guru harus memiliki sertifikat sebagai lisensi atau ijin mengajar".

Namun, apakah usaha pemerintah untuk memenuhi hak seorang guru yang sudah mendapatkan sertifikat pendidik dan menerima tunjangan profesi secara langsung dapat meningkatkan kinerja dan pada akhirnya dapat meningkatkan mutu pendidikan?

Tentu ini merupakan suatu permasalahan yang jawabannya memerlukan kajian dan penelitian intensif.

Di MTs Darussaadah Kab. Langkat, jumlah guru ada 15 dan yang sudah menikmati tunjangan profesi ada 6 orang. Berdasarkan latar belakang masalah di atas, maka permasalahannya dapat dirumuskan sebagai berikut: Bagaimana Profesionalisme guru Pendidikan Agama Islam setelah mendapat tunjangan profesi di MTs. Darussaadah Kab. Langkat.

\section{KAJIAN TEORI}

\section{Kinerja Guru}

Kinerja berasal dari kata perfomance dan sering diartikan dengan unjuk kerja atau prilaku kerja dan hasil kerja. Kinerja adalah suatu bentuk hasil kerja atau hasil usaha berupa tampilan fisik, maupun gagasan. Kinerja juga sering dihubungkan dengan kompetensi pada diri pelakunya. Kinerja Guru adalah kemampuan untuk melaksanakan pekerjaan atau tugas yang dimiliki guru dalam menyelesaikan suatu pekerjaannya. Kinerja guru tidak terlepas dari pembahasan kualitas guru itu sendiri. Kualitas merupakan istilah yang berkitan dengan sudut pandang dan sudut kepentingan pengguna istilah.

\section{Indikator Kinerja Guru}

Keberhasilan penilaian tersebut akan sangat ditentukan oleh - indikator yang telah ditetapkan sebelumnya. Untuk itu sebagai tolak ukur terhadap kinerja guru sebagaimana dimaksud dalam penelitian ini adalah motivasi, disiplin kerja, kepuasan kerja dan hubungan komunikasi dengan organisasi. 
Cybernetics: Journal Educational Research and Social Studies

Volume 2 Nomor 3, 2021

Halaman 14-28

1) Motivasi . Perasaan atau kehendak dan keinginan yang amat mempengaruhi kemauan individu, sehinga individu tersebut didorong untuk berperilaku dan bertindak kearah terealisasinya tujuan yang telah di formulasikan.

2) Disiplin kerja. Disiplin kerja, pada dasarnya dapat diartikan sebagai bentuk ketaatan dari perilaku seseorang dalam mematuhi ketentuanketentuan ataupun peraturan-peraturan tertentu yang berkaitan dengan pekerjaan, dan diberlakukan dalam suatu organisasi.

3) Kepuasan kerja. Persaan ini berupa suatu hasil penilaian seberapa jauh pekerjaannya secara keseluruhan mampu memuaskan kebutuhannya. Dalam hal ini dibutuhkan suatu evaluasi, yang kemudian dikenal dengan penilaian kinerja.

4) Hubungan dengan organisasi. Dalam penilaian kinerja melibatkan komunikasi dua arah yaitu antara pengirim pesan dengan penerima pesan sehingga komunikasi dapat berjalan dengan baik.

\section{Sertifikasi dan Tujuannya}

Pada Peraturan Menteri Pendidikan Nasional Republik Indonesia Nomor 18 Tahun 2007 tentang sertifikasi bagi guru dalam jabatan pasal 1 disebutkan :

1) Sertifikasi bagi guru dalam jabatan adalah proses pemberian Sertifikasi Pendidik untuk guru dalam jabatan.

2) Sertifikasi sebagaimana dimaksud pada ayat (1) dapat diikuti oleh guru dalam jabatan yang telah memiliki kualifikasi akademik Sarjana (S1) atau Diploma 4 (D4).

3) Sertifikasi bagi guru dalam jabatan sebagaimanadimaksud pada ayat (1) diselenggarakan oleh perguruan tinggi yang menyelenggarakan Program Pengadaan Tenaga Kependidikan yang terakreditasi dan ditetapkan oleh Menteri Pendidikan Nasional.

Jadi, sertifikasi adalah proses pemberian sertifikat pendidik untuk guru dan dosen, dan sertifikasi pendidik adalah bukti formal sebagai pengakuan yangdiberikan kepada guru dan dosen sebagai tenaga profesional. Dalam UU No. 14 Tahun 2005, pasal 4 disebut peran guru adalah agen pembelajaran, kemudian PP 19 Tahun 2005, pasal 28 (ayat 3) juga disebut agen pembelajaran pada jenjang pendidikan dasar dan menengah serta pendidikan anak usia dini meliputi :
a) Kompetensi Pedagogik;
b) Kompetensi kepribadian;
c) Kompetensi Profesional; dan 
Cybernetics: Journal Educational Research and Social Studies

Volume 2 Nomor 3, 2021

Halaman 14-28

d) Kompetensi Sosial;

\section{Tujuan dan manfaat}

Menurut Wibowo dalam Mulyasa (2005:35) mengungkapkan bahwa Sertifikasi bertujuan untuk hal-hal sebagai berikut :

1) Melindungi profesi dan Tenaga Kependidikan.

2) Melindungi masyarakat dan praktik-praktik uang tidak kompeten, sehingga merusak citra pendidik dan tenaga kependidikan.

3) Membantu dan melindungi lembaga penyenggara pendidikan, dengan menyediakan rambu-rambu dan instrument untuk melakukan seleksi dalam pelamar yang kompeten.

4) Membangun citra masyarakat dalam profesi pendidik dan tenaga kependidikan.

5) Memberikan solusi dalam rangka meningkatkan mutu pendidik dan tenaga kependidikan.

Sedangkan manfaat sertifikasi pendidik dan tenaga kependidikan adalah sebagai berikut :

\section{Pengawasan Mutu}

1) Lembaga sertifikasi yang telah mengidentifikasi dan menentukan seperangkat kompetensi yang bersifat unik.

2) Untuk setiap jenis profesi dapat mengarahkan pada praktisi untuk mengembangkan gingkat kompetensinya secara berkelanjutan.

3) Peningkatan keprofesionalisme melalui mekanisme seleksi baik pada waktu awal masuk organisasi profesi maupun pengembangan karir selanjutnya.

4) Proses seleksi yang lebih baik, program pelatihan yang lebih bermutu maupun usaha belajar secra mandiri untuk mencapai peningkatan keprofesionalisme.

\section{Kompetensi Profesional}

Rasulullah SAW pernah bersabda :

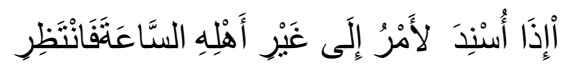

("Suatu pekerjaan yang diserahkan kepada seseorang yang bukan profesinya, maka tunggulah suatu kehancuran“Dari sabda Rosulullah SAW diatas, profesi identik dengan keahlian, seseorang yang melakukan tugas profesi juga sebagai seorang ahli (expert). Profesi mempunyai pengertian seseorang yang menekuni pekerjaan berdasarkan keahlian, kemapuan, tehnik dan prosedur berlandaskan 
Cybernetics: Journal Educational Research and Social Studies

Volume 2 Nomor 3, 2021

Halaman 14-28

intelektualitas. Istilah profesionalisme berasal dari profession. Dalam kamus Inggris Indonesia, profession berarti pekejaan, Echols dan Sadily (1996:449).

Arifin (1995:105) mengemukakan bahwa Profession mengandung arti yang sama dengan kata occupationatau pekerjaan yang memerlukan keahlianyang diperoleh melalui pendidikan atau latihan khusus. Adapun pengertian profesional Undang-Undang Republik Indonesia Nomor 14 Tahun 2005 tentang guru dan dosen adalah pekerjaan atau kegiatan yang dilakukan oleh seseorang danmenjadi sumber penghasilan kehidupan yang memerlukan keahlian, kemahiran atau kecakapan yang memenuhi standar mutu atau norma tertentu serta memerlukan pendidikan profesi.

Dari beberapa pengertian profesionalisme guru dapat disimpulkan bahwa jabatan guru tergolong jabatan profesional karena memiliki persyaratan tertentu yang telah dilakukan oleh fihak yang berwenang dan jabatan profesional tersebut mendapat pengakuan dari masyarakat dan negara.

\section{Karakteristik Kompetensi Profesional Guru}

Usman (2010:50) Karakteristik kompetensi profesional guru merupakan cerminan yang senantiasa menjadi pertimbangan untuk sosok seorang guru, khususnya dalam hal ini guru PAI yang notabene mempunyai tugas yang cukup berat dalam mengemban amanah sebagai pendidik yang diharapkan berkontribusi dan mampu mewujudkan insan kamil dan senantiasa menjadi manusia yang rahmatan lil „alamin. Adapun karakter kompetensi profesional itu sendiri, yaitu :

1) Mengausai materi bidang studi yang diajarkan, konsep dan pola pikir keilmuan yang mendukung mata pelajaran yang diampu.

2) Menguasai standar kompetensi dan kompetensi dasar mata pelajaran yang diampu.

3) Mampu mengembangkan profesionalisme secara berkelanjutan dengan melakukan tindakan reflektif.

4) Mampu memanfaatkan teknologi informasi dan komunikasi untuk mengembangkan diri.

Karena itu guru PAI dituntut untuk selalu belajar, baik yang menyangkut bidang studi yang menjadi tanggung jawabnya maupun bidang studi penunjang dan berkaitan dengannya. Penguasaan bahan oleh guru PAI akan dapat meningkatkan kepercayaan dan prestasi belajar siswa. Hal ini sangat penting dalam proses belajar mengajar, sehingga bahan pelajaran yang disampaikan guru akan diperhatikan baik-baik oleh siswa. 
Cybernetics: Journal Educational Research and Social Studies

Volume 2 Nomor 3, 2021

Halaman 14-28

Untuk lebih jelasnya tentang karakteristik kompetensi guru PAI dapat penulis jelaskan, sebagai berikut :

1) Kepribadian muslim

Menurut Allport kepribadian adalah "organisasi dinamis dalam individu sebagai sistem psikofisis yang menentukan caranya yang khas dalam menyesuaikan diri terhadap lingkungan".

Kepribadian muslim guru PAI merupakan ciri khasnya dalam berfikir, bersikap dan berprilaku yang tentunya sejalan dengan ajaran Islam. Karena itu guru PAI harus memiliki kepribadian muslim yang baik, antara lain tentang, bersemangat, gembira, sabar, ikhlas, selalu berkata baik dan tentunya juga harus jujur. Sikap dan prilaku guru demikian akan berpengaruh positif bagi minat dan perhatian siswa untuk mengikuti kegiatan belajar mengajar.

Darajat (1993:54) Guru yang goncang atau tidak stabil emosinya, misalnya mudah cemas, penakut, pemarah, penyedih dan pemurung. Anak didik akan terombang-ambing dibawah oleh arus emosi guru yang goncang tersebut karena anak didik masih dalam masa pertumbuhan jiwa itu juga dalam keadaan tidak stabil, karena masih dalam pertumbuhan dan perubahan. Biasanya guru yang tidak stabil emosinya tersebut, tidak menyenangkan bagi anak didik, karena mereka seringkali tidak dimengerti oleh guru. Kegoncangan perasaan anak didik itu akan menyebabkan berkurangnya konsentrasi fikirannya diganggu oleh perasaan yang goncang karena melihat atau menghadapi gurunya goncang. Dengan demikian kondisi guru sangat berpengaruh terhadap kegiatan belajar peserta didik.

Persyaratan Ilmiah dan kemampuan mengajar dapat dinomor duakan, sedang yang nomor satu dan tidak dapat ditawar adalah persyaratan kepribadian. Kekurangan ilmu dan ketrampilan lebih mudah memperbaiki dan meningkatkannya, dan bahayanya sebatas kepada kurangnya pengetahuan dan ketrampilan yang diperoleh siswa. Akan tetapi kekurangan persyaratan kepribadian akan menyebabkan rusaknya jiwa para siswa, mereka akan menjadi orang yang berilmu, terampil akan tetapi kepribadiannya goncang atau tidak sesuai harapan.

2) Mengelola program belajar mengajar.

Guru yang kompeten, harus mampu mengelola program belajar mengajar, seperti merumuskan tujuan pembelajaran dapat menggunakan proses intruksional dengan tepat, melaksanakan proses belajar mengajar, mengenal kemampuan peserta didik dan merencanakan serta melaksanakan program remedial.

Langkah-langkah tang harus ditempuh oleh guru dalam mengelola proses belajar mengajar yaitu, "merumuskan tujuan pembelajaran, melaksanakan 
Cybernetics: Journal Educational Research and Social Studies

Volume 2 Nomor 3, 2021

Halaman 14-28

program belajar mengajar dengan tepat, mengenal kemampuan peserta didik dan merencanakan serta melaksanakan program remedial.

3) Menggunakan media atau sumber

Kedudukan media dalam proses pembelajaran sangat penting dan diperlukan. Dengan media pengajaran penyampaian pelajaran menjadi lebih baku, pengajaran lebih menarik, pembelajaran lebih interaktif, lama waktu pengajaran yang diperlukan dapat dipersingkat, kualitas hasil belajar dapat di tingkatkan, pengajaran dapat diberikan kapan dan di mana diinginkan, sikap positif siswa terhadap apa yang mereka pelajari dan peran guru dapat berubah kearah yang lebih positif .

4) Menilai prestasi siswa untuk kepentingan pengajaran.

Untuk memperlancar interaksi kegiatan belajar mengajar, masih juga diperlukan sarana-sarana kegiatan pendukung yang lainnya, antara lain mengetahui prestasi siswa untuk kepentingan pengajaran. Persoalan ini perlu diketahui oleh guru dalam upaya meningkatkan motivasi belajar bagi para siswanya.

5) Melakukan bimbingan dan penyuluhan

Dalam tugas dan peranannya di sekolah, guru juga merupakan pembimbing atau konselor/penyuluh. Itulah sebabnya guru harus mengenal fungsi dan program layanan bimbingan dan penyuluhan serta mampu dan mau melaksanakannya.Dalam penyelenggaraan program bimbingan dan penyuluhan hendaknya guru tidak hanya terfokus kepada kegiatanyang menyangkut hal-hal yang bersifat akademis seperti koknitif, efektif dan psikomotorik sajatetapi lebih dari itu seorang guru kompeten diharapkan mampu memberikan pelayanan tentang problem-problem pribadi siswa yang memungkinkan, sehingga dengan demikian anak didik dapat mengembangkan potensinya secara optimal dan semangat karena merasa dia tidak sendirian ketika dalam permasalahan, ada guru yang bisa membantunya.

6) Menyelenggarakan administrasi sekolah

Guru di sekolah disamping berperan sebagai pengajar,pendidik dan pembimbing juga sebagai administrator.Dengan demikian maka guru harus mengenal dan menyelenggarakan administrasi sekolah, sebab administrasi sekolah sangat menunjang pelaksanaan proses pembelajaran.

7) Memberikan penghargaan

Penghargaan merupakan bentuk motivasi yang sangat penting diberikan kepada siswa. Apabila ada siswa yang sukses dan berhasil mengerjakan tugas dengan baik atau mendapatkan prestasi terbaik lainnya tentunya sah-sah saja jika ia harus mendapatkan sebuah penghargaan dari guru. Penghargaan tersebut merupakan bentuk reinforcemen yang positif dan sekaligus 
Cybernetics: Journal Educational Research and Social Studies

Volume 2 Nomor 3, 2021

Halaman 14-28

merupakan motivasi. Dengan penghargaan yang tepat akan memupuk suasana yang menyenangkan dan mempertinggi gairah belajar serta dapat membangkitkan harga diri.

\section{Syarat-syarat Menjadi Guru Profesional}

Menjadi seorang guru bukanlah pekerjaan yang gampang, seperti yang dibayangkan orang, dengan modal penguasaan materi dan penyampaian kepada siswa sudah cukup, hal ini bukanlah dikategorikan sebagai guru yang memiliki pekerjaan profesional karena guru yang profesional, mereka harus memilikiberbagai ketrampilan, kemampuan khusus, mencintai pekerjaannya, menjaga kode etik guru dan lain sebagainya sebagaiman filosofi Ki Hajar Dewantara;"Tut Wuri Handayani", ing ngarso sung tulodho, ing madya mangun karso.

Hamalik (1990:118) Guru tidak cukup dengan menguasai materi pelajaran akan tetapi mengayomi murid, menjadi contoh atau teladan bagi murid serta selalu mendorong murid untu k lebih baik dan maju.

Guru profesional harus memiliki persyaratan yang meliputi :

1) Memiliki bakat sebagai guru.

2) Memiliki keahlian sebagai guru.

3) Memiliki keahlian yang baik dan terintegrasi.

4) Memiliki mental yang sehat.

5) Berbadan sehat

6) Memiliki pengalaman dan pengetahuan yang luas.

7) Guru adalah manusia berjiwa Pancasila.

8) Guru adalah seorang warga Negara yang baik.

\section{Aspek-Aspek Kompetensi Guru Profesional}

Kompetensi pedagogik, kompetensi kepribadian, kompetensi sosial dan kompetensi profesional yang diperoleh melalui pendidikan profesi. Di dalam peraturan pemerintah Republik Indonesia nomor 19 Tahun 2005 tentang Standar Nasional Pendidikan Pasal 28 ayat 3 "Kompetensi sebagai agen pembelajaran pada jenjang pendidikan dasar dan menengah serta pendidikan anak usia dini meliputi :
a. Kompetensi pedagogik.
b. Kompetensi kepribadian.
c. Kompetensi profesional.
d. Kompetensi sosial. 
Yang dimaksud dari keempat kompetensi di atas adalah sebagai berikut:

1) Kompetensi Pedagogik Kompetensi pedagogik adalah kemampuan mengelola pembelajaran peserta didik yang meliputi pemahaman terhadap peserta didik, perancangan dan pelaksanaan pembelajaran, evaluasi hasil belajar, dan pengembangan peserta didik untuk mengaktualisasikan berbagai potensi yang dimilikinya.

2) Kompetensi Kepribadian Kompetensi kepribadian adalah kemampuan kepribadian yang mantab, stabil,dewasa, arif dan berwibawa, menjadi teladan bagi peserta didik dan beakhlak mulia.

3) Kompetensi Profesional Kompetensi profesional adalah kemampuan penguasaan materi pembelajaran secara luas dan mendalam yang memungkinkannya membibing peserta didik memenuhi stndar kompetensi yang ditetapkannya dalam standar Nasional Pendidikan.

Kompetensi Sosial Kompetensi sosial adalah kemampuan guru/pendidik sebagai bagian dari masyarakat untuk berkomunikasi dan berinteraksi secara efektif dan efisien dengan peserta didik, sesama guru, tenaga kependidikan, orang tua/ wali peserta didik, dan masyarakat sekitar.

\section{METODE PENELITIAN}

Jenis penelitian ini adalah kualitatif lapangan (Grounded) dengan menggunakan pendekatan diskriptif kualitatif fenomenologi yaitu mengumpulkan data sebanyak-banyaknya mengenai kinerja guru PAI setelah mendapat tunjangan profesi. Sumber data dalam penelitian ini antara lain :

1. Kepala sekolah, Guru dan Siswa di MTs Darussaadah Kab. Langkat,.

2. Dokumentasi (file) tentang kinerja guru PAI dalam mendukung tercapainya Program Sertifikasi Guru.

3. Rekaman hasil pengamatan.

Sedangkan teknik pengumpulan datanya dengan menggunakan metode: 1) Wawancara, 2) Observasi, 3) Dokumentasi.

Dalam Penelitian ini menggunakan analisis diskriptif kualitatif. Menurut Milles and Hubberman, analisa data dalam penelitian kualitatif adalah pada saat pengumpulan data berlangsung dan mepunyai langkah-langkah sebagai berikut:

a. Data reduction (Reduksi Data)

Data yang diperoleh dilapangan jumlahnya cukup banyak maka datadata yang ada perlu dicatat secara rinci. Mereduksi data berarti merangkum memilih hal-hal yang pokok dan menfokuskan pada hal-hal 
yang penting serta mencari tema dan polanya. Karena data yang direduksi akan memberikan gambaran yang lebih jelas dan akan mempermudan untuk mendapatkan data selanjutnya.

b. Data display (Penyajian data)

Maksud dari data display adalah mengumpulkan data dan mengorganisir data dari informasi yang dikumpulkan dari berbagai cara baik data yang berbentuk uraian singkat maupun teks yang bersifat naratif sehingga dengan mendisplay data akan mempermudah untuk memahami apa yang terjadi.

c. Conclusion Drawing (Verification)

Milles and Hubermanda dalam Sugiyono (2009:252) menjelaskan bahwa langkah selanjutnya dalam penelitian kualitatif adalah penarikan kesimpulan dan verifikasi. Karena kesimpulan awal yang sudah di kemukakan adalah masih sementara dan akan berubah bila tidak ditemukan bukti-bukti yang kuat yang mendukung pada tahap pengumpulan data selanjutnya. Adapun untuk mendapatkan kesimpulan yang valid maka peneliti harus melakukan "cek silang" dengan data-data yang terkait dan cara untuk mengecek informasi.

\section{HASIL DAN PEMBAHASAN PENELITIAN}

\section{Penilaian Kepala Madrasah /Sekolah terhadap Kinerja Guru Pasca Sertifikasi}

Disamping menggunakan instrumen penilaian kinerja penulis juga melakukan wawancara khusus kepada kepala Madrasah Tsanawiyah Darussaadah mengenai kinerja guru sertifikasi. Berdasarkan hasil wawancara 10 Desember 2020 yang dilakukan dengan kepala madrasah/ sekolah, sesuai dengan pertanyaan yang saya ajukan yakni tentang aspek-aspek yang dapat dijadikan ukuran dalam mengkaji kinerja guru, antara lain:
a. Quality of work = mutu pekerjaan,
b. Promptness = ketepatan waktu
c. Initiative $=$ prakarsa
d. Communication $=$ komunikasi

Diketahui bahwa kepala madrasah / sekolah menilai kinerja guru yang sudah lulus sertifikasi sudah mendekati standar kinerja yang berlaku. Peningkatan yang dinilai telah dialami diantaranya adalah: pada aspek perencanaan pembelajaran, dan ini adalah salah satu mutu pekerja antara lain guru telah mampu menyusun program tahunan, dan hasilnya sudah cukup lebih baik serta disusun lebih awal dari sebelumnya. Selain sudah dibuat pada setiap tatap muka (disesuaikan dengan kebutuhan). Pada aspek pelaksanaan pembelajaran, guru sudah menggunakan sebagai media/ alat praga. Kepala 
melaksanakan supervisi terkadang juga tidak secara langsung dan tidak jarang beliau mengitari disekitar halaman kelas dengan mengamati guru, dengan cara membersihkan tanaman dihalaman kelas. Berdasarkan apa yang didengar dan dilihat dari luar kelas. Beliau memeng mengatakan bahwa ada salah satu guru yang kurang menguasai kelas atau kurang menguasai materi maka guru tersebut akan dipanggil.

Diantara pembinaan guru mengenai peningkatan pendidikan agama islam ada juga pembinaan guru setiap 1 bulan sekali diadakan pertemuan untuk guru yang bertempat dirumah guru secara bergantian, acaranya dimulai dengan membaca istighosah beserta do"a bersama.

Kemudian untuk ketepatan waktu beliau mengungkapkan bahwasanya di MTs Darussaadah Kab. Langkat itu untuk semua gurunya baik yang belum sertifikasi atau guru yang telah sertifikasi itu dituntut untuk disiplin tinggi. Untuk kemampuan guru, untuk ketentuan sertifikasi sebaiknya guru itu harus memiliki kompetensi sesuai dengan sertifikat pendidiknya, pertanyaan yang saya ajukan apakah kinerja guru sertifikasi sudah mencapai optimal, hal ini kami dapatkan informasi dari kepala madrasah bahwa kwalitas RPP yang telah disusun oleh guru pasca sertifikasi, kalau ujian juga sudah membuat soal sendiri beserta kisi-kisinya, kisi-kisi kan isinya ada setandart kompetensi . indikator, soal dan jawaban. Untuk penyetoran nilai juga langsung dianalisis ulangan-ulangan harian.

\section{Faktor Penghambat Peningkatan Kinerja Guru}

Berdasarkan hasil wawancara yang dilakukan dengan kepala madrasah sekolah, diketahui bahwa ada sedikit faktor penghambat kinerja guru. Kendala yang ada, yaitu masih ada salah satu yang malas dalam hasil perencanaan pembelajaran, beberapa faktor penghambat yang dirasakan adalah: kurangnya respon anak-anak dalam materi alqur"an dan hadist- hadist, untuk guru kelas juga terlalu banyak materi yang akan disiapkan.

Dalam pelaksanaan pembelajaran, faktor penghambat yang dirasakan antara lain adalah: a. Perbedaan karakteristik siswa yang menyulitkan guru. dan b. Kurangnya alokasi waktu yang tersedia.(wawancara dengan bapak Aspan, S.Pd.I. ) Dalam penilaian pembelajaran, faktor penghambat antara lain dirasakan adalah: perbedaan karakteristik siswa yang menyulitkan guru.

Dalam pengembangan profesi, faktor penghambat yang antara lain dirasakan adalah: kesibukan lain diluar kegiatan madrasah/sekolah, akan tetapi madrasah mempunyai kegiatan terdendiri. 


\section{Faktor Penunjang Peningkatan Kinerja Guru}

Sebagaimana faktor-faktor penghambat, berdasarkan hasil wawancara yang dilakukan dengan kepala madrasah/sekolah juga ditemukan faktor pendukung peningkatan kinerja guru. Dalam perencanaan pembelajaran, faktor-faktor pendukungnya adalah:

a. Adanya kemauan untuk maju sehingga mendorong para guru berbuat lebih baik.

b. Kerjasama yang baik antara kepala madrasah/sekolah, guru dan para staf-staf pembantu. Dan

c. Adanya supervisi yang dilakukan baik oleh kepala maupun pengawas.

Dalam pelaksanaan pembelajaran, faktor pendukungnya antara lain adalah: 1) Pengalaman mengajar yang dimiliki oleh guru telah cukup lama dan 2) Kerjasama yang baik antara kepala madrasah/ sekolah, guru dan staf-staf pembantu.

Dalam penilaian pembelajaran, faktor pendukungnya adalah: kerjasama yang baik antara guru dan kepala madrasah/sekolah. Dalam pengembangan profesi, faktor pendukungnya antara lain adalah:

1) Adanya kegiatan KKG, penataran, dan lain-lain yang diadakan oleh Diknas maupun Depag.

2) Adanya tunjangan profesi yang berarti peningkatan kesejahteraan guru. dan

3) kerjasama yang baik antara guru dan kepala madrasah/ sekolah

\section{KESIMPULAN}

Berdasarkan hasil penelitian diatas penulis dapat mengambil kesimpulan sebagai berikut : 1) Kinerja guru pendidikan agama islam MTs Darussaadah Kab. Langkat dilihat dari hasil asian instrumen penilaian kinerja guru rata-rata mempunyai hasil nilai yang baik, 2) Dalam pelaksanaan peningkatan kinerja guru di MTs Darussaadah terdapat faktor-faktor pendukung antara lain : a) Adanya kemauan untuk maju sehingga mendorong para guru berbuat lebih baik, b) Kerjasama yang baik antara kepala madrasah/sekolah, guru dan para staf-staf pembantu. Dan Adanya supervisi yang dilakukan baik oleh kepala maupun pengawas. 
Cybernetics: Journal Educational Research and Social Studies

Volume 2 Nomor 3, 2021

Halaman 14-28

\section{DAFTAR PUSTAKA}

Ahmad Tafsir, Ilmu Pendidikan Dalam Perspektif Islam, (Bandung: PT Remaja Rosyad Karya, 2008)

Ali Mudlofir, Peningkatan Guru Agama Islam, (Jakarta: Ditjend Pendis Kemenag RI, 2011 cet.Ke-1)

Arifin, Kapita Selekta Pendidikan (Islam dan Umum), (Jakarta: Bumi Aksara, Cet Ke-3, 1995)

Asrorun Ni"am Sholeh, Membangun Profesi Analisis Guru Analisis KronologisAtas Lahirnya UU Guru Dan Dosen, (Jakarta: Elsas, 2006)

Beni Ahmad Saebani, Metode Penelitian, (Bandung: CV Pustaka Setia, 2008)

Buchari Alma, Guru profesional, (Bandung: CV. Alfabeta, 2009) Daradzat, Zakiyah. Pendidikan Islam Dalam Keluarga Dan Sekolah, (Bandung: Rosda karya, 1993)

John M Echols dan Hasan Sadily, Kamus Inggris Indonesia, (Jakarta,PT. Gramedia, ,Cet.ke -23, 1996)

Kunandar, Guru Profesional Implementasi Kurikulum Tingkat Satuan Pendidikan (KTSP).

Martinis Yamin, Profesionalisasi guru Dan Implementasi KTSP, (Jakarta: Gaung Persada Press, 2009)

Martinis Yamin, Sertifikasi Profesi Keguruan Di Indonesia. (Jakarta: Gaung Persada Press, 2009)

Masnur Muslikh, Sertifikasi Guru Menuju Profesionalisme Pendidik, (Jakarta: PT Bumi Aksara, 2007)

Mulyasa, Standart Kompetensi Dan Sertifikasi Guru, (Bandung: PT. Remaja Rosda Karya, 2005)

Nanang Hanafiah \& Cucu Suhana, Konsep Strategi Pembelajaran, (Bandung: PT. Refika Aditama, 2009)

Oemar Hamalik, MetodeBelajar Dan Kesulitan-KesulitanBelajar (Bandung: Tarsito, 1990)

Ondi Soandi dan Aris Suherman, Etika Profesi Keguruan, (Bandung: PT. Retika Aditama, 2010)

Rusman, Model-Model Pembelajaran Mengembangkan profesionalisme Guru, (Jakarta: PT. Raja Grafindo Persada, 2010)

Sugiyono, Metode Penelitian Kuantitatif Kualitatif Dan RED, (Bandung: PT. Alfabeta, 2009)

Tabrani Rusyan, A. dan M.Sutisna WD, Kesejahteraan Dan Motifasi Dalam Meningkatkan Efektifitas Kinerja Guru. (Jakarta: Intimedia Cipta Nusantara, t.t.) 
Cybernetics: Journal Educational Research and Social Studies

Volume 2 Nomor 3, 2021

Halaman 14-28

Uzer Usman, Moh., Menjadi Guru Profesional, (Bandung: PT. Remaja Rosda Karya, 2010)

UU RI No.14 Tahun 2005 Tentang Guru dan Dosen UUD 1945

Yunus Namsa, M., Kiprah Baru Profesi Guru Indonesia Wawasan Metodologi Pengajaran Agama Islam, 